\title{
A Theoretical Model of Factors Influencing IT Adoption in Nigerian Construction Organizations
}

\author{
Dr. A. Y. Waziri ${ }^{\# 1}$, Mustapha Y. ${ }^{* 2}$, Dr. Katun M. Idris ${ }^{\# 3}$ \\ Department of Quantity Surveying, Abubakar Tafawa Balewa University, Bauchi, Nigeria \\ Department of Quantity Surveying, Abubakar Tafawa Balewa University, Bauchi, Nigeria \\ Department of Quantity Surveying, Federal Polytechnic, Bauchi, Nigeria \\ ${ }^{1}$ aywaziri@gmail.com \\ 2 citihills@gmail.com \\ 3 idriskt@gmail.com
}

\begin{abstract}
Information and communication technology has been a driving force behind organizational performance through stimulation and standardization of a smooth and effective communication among the members of organizations as well as inter-organizational collaborations. As these technological advancements have been progressing significantly faster in other countries, the Nigerian construction organizations have lagged behind many of its developing country counterparts in terms of acceptance, usage and adoption of these technologies. Consequently, there is low level of IT utilization in the Nigerian construction industry. Through an extensive review of literatures emanating from Nigeria, this study examined the causes of low IT adoption among Nigerian construction organizations and developed a theoretical model of IT adoption using T-O-E Framework (Technology, Organization and Environment) as a theoretical basis to guide the IT adoption process. Findings from the study reveal that construction organizations are reluctant to adopt new technologies due to unfavourable economic environment. The study further found that the successful adoption of IT is hinged on the alignment of technology, organization and environmental variables of an organization. It is recommended that the construction managers should tackle resistance to change among themselves and their employees and create readiness in their respective organizations for successful IT acceptance and use.
\end{abstract}

Keyword-Construction Organizations, Construction Industry, IT Adoption, IT Acceptance, Resistance to Change

\section{INTRODUCTION}

The implementation of IT in construction organizations has numerous advantages. Although the significance of the IT adoption to the industry should be assessed based on the roles it played in assisting the industry towards successfully meeting its goals. According to [1], IT adoption improves the performance processes of construction in terms of cost, time, quality and general client satisfaction. This is possible since IT adoption improves the completion time of tasks or operations, enhance collaboration among construction team members, enables accessibility and general exchange of information. Furthermore, a successful adoption of IT by a construction firm has positive effects on its performance, competitive advantage, easier information exchange and presentation of new business openings.

The contribution of construction outputs to sustainable economic growth and development of a country is highly significant [2]. The Nigerian construction industry is not an exception. In fact, it is a major stimulant of the nation's economic and social growth. Nigerian construction industry accounts for about 3-8\% of gross domestic product (GDP), employs 5\% of the entire country's labour force, 40-70 of the gross fixed capital formation and about $12 \%$ of production in the industrial sector. This enormous wealth creation and generation by the industry places it among the key sector of the country's economy. The massiveness of the industry and the interaction of its stakeholders demand a modern means of running its organizations for improved production. While the use of information and communication technologies among the construction organizations in Nigeria have been tremendously improving over the years, the adoption is generally limited to basic computer skills and use of professional software. Advanced IT adoption such as e-tendering, computerized inventory control, advanced project management and scheduling systems, modelling and simulation technologies or electronic data interchange are rarely evidenced among the construction organizations.

It is essential, therefore, to carry out a comprehensive study aimed at unveiling the issues facing the Nigerian construction organizations which led to low level of IT utilization with a view to curtailing the continuous occurrence of the menace. To this end, this study examined the various problems faced by Nigerian construction organizations during IT adoption and developed a theoretical model of IT acceptance using TOE framework to address the issue 
The paper is structured into five sections: section one introduces the topic and clearly stated the aim of the research. Section two discusses the existing models of IT adoption in organizations. Section three examines the problems of IT adoption faced by Nigerian construction organizations and presents summarized literature of IT adoption researches in Nigeria. Section three of the research discusses the theoretical framework as well as relevant constructs used in developing the theoretical model. The last section presents results of the study and dwells on implications, recommendations and areas for further study..

\section{EXISTING Models of IT AdOPTION IN ORgANizATIONS}

Many models have been developed to address IT adoption in organizations with individual models using specific variables. For instance, [3] developed a theoretical framework of the key factors affecting the adoption of technology in the Nigerian construction firms. The model was designed in relation to Roger's diffusion of innovation theory in which culture, policy and cost were highlighted as the key variables influencing an organization's decision to adopt and use ICT. The major drawdown of the study, however, was the context in which Roger's diffusion of innovation theory was used. Rather than looking at the actual adoption, the theory seeks to explain the adoption rate in a given unit of analysis (organization, sector etc). Another prominent model of IT innovation adoption in organizations was that of [4]. The authors proposed a conceptual model of IT acceptance utilising diffusion of innovation theory, theory of reasoned action, technology acceptance model and theory of planned behaviour capturing innovation, organization, environment and CEO characteristics as the major variables. While the study was exhaustive, it was not specific as to the type of organization targeted and the environmental context in which the study was meant to addressed. This study targets IT adoption in the Nigerian construction industry taking into account the relevant contextual issues. Similarly, [5] proposed a model by examining the factors affecting IT adoption in SMEs. Using structural equation modelling, the authors found that readiness and preparedness of organizations have a positive influence on the successful adoption of IT. The study was however conducted in central Java region, Indonesia. Furthermore, though the study was empirical, it used little sample sample size (60 respondents) and the environmental characteristics of Indonesia may be different from that of Nigeria. Accordinng to [6], there is significant differences in contextual characteristics among developing countries. The model proposed by [7] employed resources dependency theory and diffusion of innovation theory arguing that the influence of innovation characteristics and power exercise can explain B2B EC adoption. While this proposition, according to the authors, could improve understanding of B2B EC adoption and helps to resolve inconsistency of findings in the literature, the study left out significant variables (such as technology, people and environment) in the model. Furthermore, the study was not addressing IT adoption in construction organization in addition to difference in environmental context. In another IT adoption model, [8] presented a model encompassing technology acceptance model, diffusion of innovation theory, technology-organization-environment framework, human-environmental model, IT governance framework and other sociological paradigms such as the functionalist, the interpretive, the radical structuralist and radical humanist paradigms. According to the authors, the complexity of the model was meant to address various problems situations of an organization from multiple perspectives. The model was rather complex and IT adoption models in organizations should be as simple as possible to warrant successful implementation.

Based on the reviewed models above emanating from extant literatures, this study sets out to develop a theoretical model of IT adoption in construction organizations with specific reference to Nigeria. The study first examine the various problems hindering IT initiation and subsequent acceptance and went further to incorporate the drivers necessary for successful implementation. Thus, a theoretical model relating technology, organization and environment variables was proposed based on TOE framework as a theoretical basis.

\section{The CAUSES OF LOW IT Adoption AMONG Nigerian CONSTRUCTION ORganizations}

Like most developing countries, the Nigerian construction organizations are faced with numerous challenges which hinder them from successful IT adoption. Quite a substantial number of researches have been carried out on IT adoption among Nigerian construction organizations. Most of the studies however are specific to a particular professional organization. For instance, in one of the earliest IT studies [9] administered a handful of questionnaires to small, medium and large construction firms and sites in Jos and Abuja to investigate the application of computers in the management of building projects in Nigeria. The researcher found that the average percentage application of computers in executing construction management functions in Nigeria is $62 \%$. It was also evidenced from the study that the larger the construction firm, the more likelihood of computer application.

A more advanced study [10] was conducted thereafter to investigate the use of ICT in construction organizations. The author ranked the constraints to IT adoption thus: (i) inadequate/erratic power supply (ii) high cost of hardware and software (iii) lack of sufficient jobs (iv) fear of virus attack (v) high rate of obsolescence of hardware/software (vi) inadequate ICT content of construction education (vii) high cost of employing computer professionals (viii) lack of appreciation of ICT by firm's management (ix) security/privacy fear (x) low return on investment (xi) fear of mass job losses in the industry (xii) fear of personal abuse and (xiii) fear of ICT making professionals redundant. Similarly, [11] surveyed the use and impact of information 
technology in quantity surveying service delivery in Nigeria. The research found that the main reasons for nonutilization of IT by QS firms are: financial barrier, ignorance of the advantages of IT, fear of new technology, resistance to changes and lukewarm attitude towards information technology

The Nigerian construction industry is composed of many small indigenous firms who compete with the foreign companies. A study [12] to examine the challenges facing SMEs in IT adoption from southwestern Nigeria revealed interesting results. The major problems facing SMEs in IT adoption as revealed by the study are: lack of infrastructural facilities, corruption, cost of implementation, lack of funds, lack of awareness among owners-managers, lack of skills and training, cultural factors, lack of government policies that support ICT adoption in SMEs and electricity constraints. Furthermore, [13] investigates the reasons for non-utilization of ICT by SMEs in Nigeria and found that the inhibiting factors are electricity, lack of infrastructure, poor service from ISP provider, lack of education, lack of support from government and banks and cost of training and maintenance. The study confirmed the most of the major problems of IT adoption as reported in most literatures from Nigerian context.

Numerous evidences from existing literature supports Nigerian government's indifference on IT adoption not only in organizations but even in government. According to [14], the failure of Nigerian government to fully embrace e-government adoption is as a result of low ICT literacy rate, lack of regulatory framework, poor ICT infrastructures, corruption, lack of committed leadership, epileptic power supply and bureaucratic bottlenecks. These constraints have spilled to not only construction organizations but the entire organizations from other sectors of the economy.

TABLE I- Conceptualization of Research Variables

\begin{tabular}{|c|c|c|c|}
\hline Constructs & Concepts & Variables & References \\
\hline $\begin{array}{l}\text { Technology } \\
\text { Context }\end{array}$ & $\begin{array}{l}\text { Readiness for Change } \\
\text { Technology Competence } \\
\text { Top Management Support } \\
\text { Organizational Resources }\end{array}$ & $\begin{array}{l}\text { Low level of advanced IT usage } \\
\text { inadequate ICT content of construction education } \\
\text { lack of skills and training } \\
\text { low ICT literacy rate } \\
\text { lack of committed leadership } \\
\text { high cost of hardware and software } \\
\text { high cost of employing computer professionals } \\
\text { low return on investment } \\
\text { financial barrier } \\
\text { cost of implementation } \\
\text { cost of training and maintenance }\end{array}$ & $\begin{array}{l}\text { Achuenu, } \\
(1999) \\
\text { Oladapo, } \\
\text { (2007) } \\
\text { Apulu \& } \\
\text { Ige, (2011) } \\
\text { Omeire and } \\
\text { Omeire, } \\
\text { (2014) }\end{array}$ \\
\hline & & $\begin{array}{l}\text { fear of virus attack } \\
\text { security/privacy fear }\end{array}$ & \\
\hline $\begin{array}{l}\text { Organization } \\
\text { Context }\end{array}$ & Resistance to Change & $\begin{array}{l}\text { lack of appreciation of ICT by top management } \\
\text { fear of mass job losses in the industry } \\
\text { fear of ICT making professionals redundant } \\
\text { fear of new technology } \\
\text { resistance to changes } \\
\text { lukewarm attitude towards information technology }\end{array}$ & $\begin{array}{l}\text { Ibironke, } \\
\text { (2011) }\end{array}$ \\
\hline $\begin{array}{l}\text { Environment } \\
\text { Context }\end{array}$ & $\begin{array}{l}\text { External Environment } \\
\text { Competitive Pressure } \\
\text { Government Support } \\
\text { Regulatory Framework }\end{array}$ & $\begin{array}{l}\text { lack of sufficient jobs } \\
\text { inadequate/erratic power supply } \\
\text { lack of infrastructural facilities } \\
\text { electricity constraints } \\
\text { epileptic power supply } \\
\text { bureaucratic bottlenecks } \\
\text { lack of government policies that support ICT } \\
\text { adoption }\end{array}$ & $\begin{array}{l}\text { Oladapo, } \\
\text { (2007) } \\
\text { Apulu \& } \\
\text { Latham, } \\
(2009)\end{array}$ \\
\hline
\end{tabular}




\section{IV.THEORETICAL BACKGROUND}

The TOE framework offers an advantageous analytical framework that can be used for studying IT adoption in construction organizations. The TOE is developed by [15] who theorized that the possibility that an organization adopt and implement IT is determined by the technology, organization and environment contexts of the organization. The technology context comprises IT infrastructure competence and e-business know-how, organizational size, top management support, technology competence, adequate skilled IT personnel, security concerns. The organization context includes firm characteristics such as linking structures between employees, intra-firm communication processes, organizational culture and organizational change processes. The environment context embraces external environmental characteristics such as regulatory environment, structure of the industry, presence or absence of technology service providers and competition. According to [16], the specific factors used within each adoption context (i.e technology, organization and environment contexts) vary across different studies. In this study, the technology context is operationalized by technology competence, top management support, organizational resources and security. The organization context comprises of resistance to change and the environment context variables are competitive pressure, government support and regulatory framework.

\section{A THE TECHNOLOGY CONTEXT}

This section discusses the technology competence, top management support, organizational resources and security and their impact on IT adoption in construction organizations.

\section{Technology Competence}

The employees' ability to handle task effectively and productively by the use of technology is what is referred to technology competence [17]. Technology competence is a function of some organizational dynamics. The level of availability and sophistication of IT infrastructure, technical expertise and knowledge level determine the competence (in technological terms) of an organization [18]. According to [19], organizations with adequate and skilled technical staffs adopt and successfully use IT systems profitably since IT set-ups explain relations between technical and social systems. Furthermore, the level of compatibility of a certain technological system and the current organizational skills encourages faster acceptance of technology into an organization [20].

\section{Top Management Support}

The support provided by top managers of an organization during IT adoption plays a vital role in its success. According to [21], once top management understands the significance of the IT system to be implemented, they encourage and motivate employees to buy-in to the adoption. In this instance, top managers allocate adequate financial resources necessary to set-up the system. Similarly, [22] observed that top managers offer and supplies sufficient financial resources which enable the acquisitions of proper technical equipment and external expertise.

\section{Organizational Resources}

Availability of resources in form of both human and financial resources is vital in organization's decision to adopt IT systems. This explains why small firms with inadequate capital base have low rate of IT adoption and other technological investments [23]. Most organization managers perceived the cost of IT tools and equipment as high thus discouraging investment in IT systems.

\section{Security}

The problem of data security due to actions of hackers has been a major area of concern nowadays in computerization of organizations [24]. Feelings of discomfort and insecurity in IT usage are manifested in various ways and cultures and influence consumer trust in patronizing electronic-based business service [25]. Security occurrences in form of virus attack, spyware infection and cyber fraud affects level of organizational confidence on IT usage.

\section{B THE ORGANIZATION CONTEXT}

Resistance to change is an element in organizational system that hinders change to take place. According to [26], resistance to change is any conduct that serves to maintain the status quo in the face of pressure to alter the status quo. Resistance comes not just from employees but management as well. Managers of construction organizations in Nigeria fear that the introduction of IT into their organizations would take over their jobs and make them redundant [27]. Furthermore, construction professionals resist change by fearing the use of new technology. Changing organization's operational processes is inevitable but the manner and methods used in introducing the change is misunderstood by both the top managers and the employees.

\section{THE ENVIRONMENT CONTEXT}

This section discusses competitive pressure, government support and regulatory framework as external variables affecting IT adoption and reflects upon their significance in successful IT adoption. 


\section{Competitive Pressure}

The level of competition among business organizations considerably brings about fast-paced technological change and better firm performance [28]. Competition arises from rivalry among firms for customer attention [29] to increased market share and profit margin. This led firms to introduce change into their businesses in order to remain relevant. Technological change is common in today's business environment. Pressure from competitors significantly affects firm's intention to adopt and use IT [30]. Adoption of each IT technology may exhibit a different scale of pressure for a firm.

\section{Government Support}

IT adoption in developing countries suffers setback primarily due to inability of the state to provide adequate electricity supply and support organizations with incentives.. In order to help and encourage IT adoption and usage in a country, the government provides adequate electricity and other infrastructures suitable for IT implementation. This motivates managers of organizations to act towards computerizing their organizations. According to [31], rapid and massive progress in IT adoption by some Asian economies (Korea, Japan, Singapore, Malaysia etc.) was attributable to the role played by government.

\section{Regulatory Framework}

The IT regulatory framework should be structured so as to accommodate new technology adoption. For instance, the government should make it compulsory for all tendering processes to be conducted electronically. Appropriate policy design should be provided prior to IT implementation. The IT policy should then be followed with sound economic policies capable of stimulating investments in IT infrastructures and services [32].

\section{Theoretical Model of IT Adoption in Construction Organizations}

Figure 1 below presents a theoretical model of IT adoption in construction organizations based on the theoretical idea of technology acceptance using TOE framework. As earlier on highlighted, the technology context comprises of technology competence, top management support, organizational resources and security. The organization context addresses resistance to change while environmental context contains variables such as competitive pressure, government support and regulatory framework.

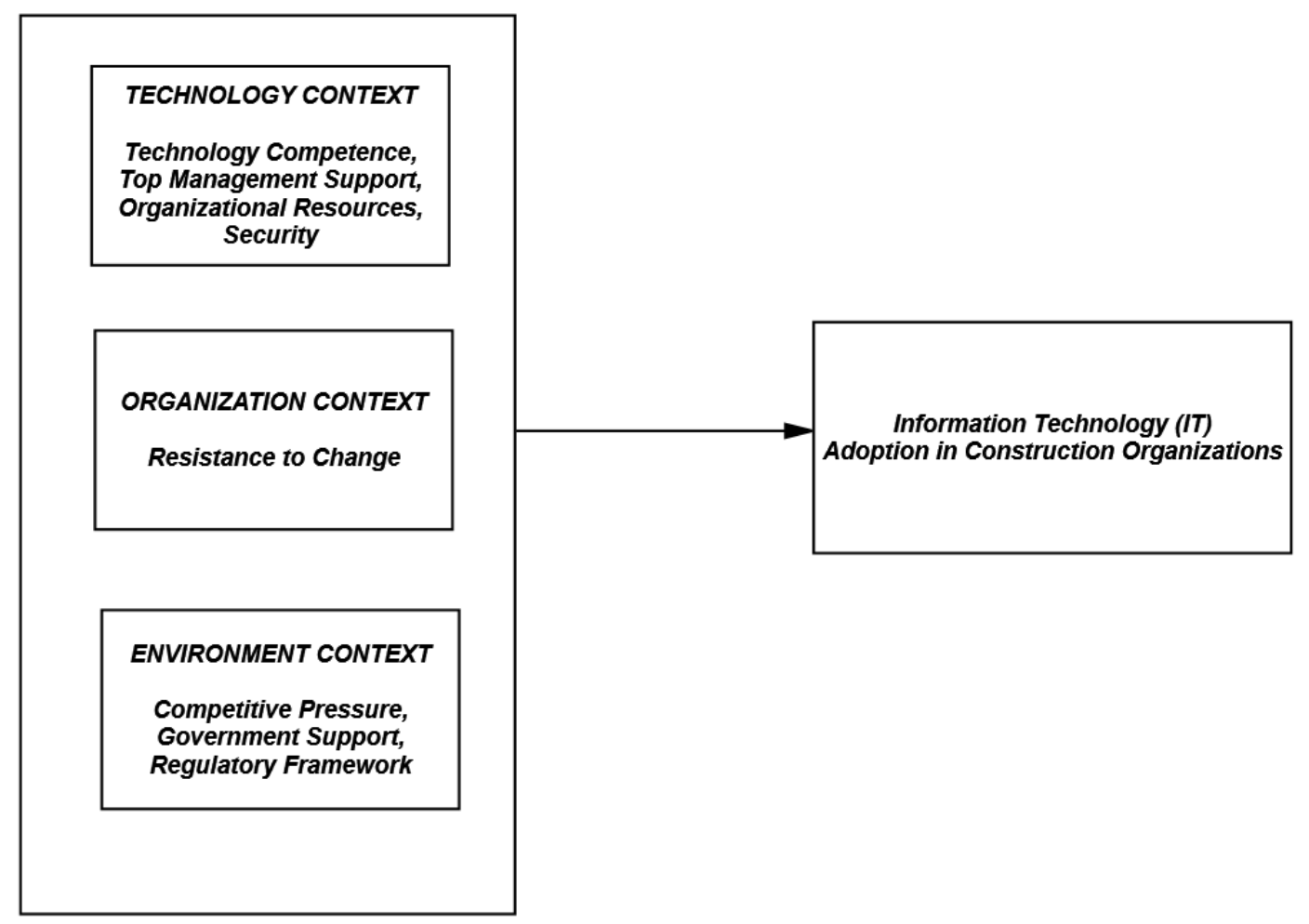

Fig. 1: Theoretical Model of IT Adoption in Construction Organizations 


\section{DISCUSSION OF RESULT}

This study attempts to address low level of IT utilization in construction organizations by proposing a theoretical model using TOE framework. Firstly, studies focusing on IT adoption constraints were reviewed and the extracted variables were operationalised for easy classification of variables under their respective contexts.

Technology wise, findings show that for a successful adoption of IT in construction organizations, there is the need for adequate technical staffs with required technical expertise and IT equipment. Additionally, top managers must support and encourage the technical implementation and help in end-user acceptance and use. Furthermore, there should be sufficient resources for the acquisition of IT tools and their maintenance.

Organization wise, top managers do not appreciate IT system and the idea of their usage. This is as a result of their fear for technology. There is the general fear among both professionals and managers of construction firms that IT adoption would make them redundant and irrelevant in the construction industry.

Environment wise, results have shown that competition among construction organizations results in faster acceptance and diffusion of technology among organizations. Competition compels firms to introduce change to improve their business performance. Furthermore, provision of adequate electricity and IT infrastructures by government has been found to significantly influence IT adoption. Lastly, the IT regulatory framework when appropriately structured accommodates IT adoption within an entire economy.

\section{CONCLUSION}

This study was set out to address the problem of low IT adoption in Nigerian construction organizations. Findings from this study show that TOE framework is a valid model to understand the adoption and use of IT in construction organizations. The successful adoption of IT is hinged on the alignment of technology, organization and environmental variables of an organization. Specifically, the presence of skilled IT personnel, enthusiastic top managers adequate organizational resources for the acquisition and maintenance of IT systems and server security is needed to actualize IT in construction organizations. Furthermore, the construction managers exhibit a significantly high level resistance which hinders their willingness to accept and use IT in their organizations. Construction organizations are not ready to invest heavily on IT applications since the whole economic environment and trading partners are not utilizing e-business solutions. For successful IT adoption in construction organizations, it is critical for construction managers to tackle resistance among themselves and the employees as resistance to change comes not just from employees but management as well. Lastly, Competitive pressure as an external environment variable exert a significant effect on IT adoption. Consequently, construction organizations with high level of ICT facilities are more competitive, enjoy greater benefits and are perceived favourable by customers. Government support is also an important factor affecting IT adoption in construction organizations. Results of the study suggest that provision of incentives to firms by government aids in effective implementation and utilization of IT in the construction industry. Additionally, improvement and adequate provision of IT infrastructures could potentially support IT adoption among firms. Consequently, the construction professionals believed that government should serve as a role model for the construction organizations through implementation of IT innovations such as e-government and e-tendering. This would speed up the IT adoption within the industry and its subsequent diffusion into other industries. Therefore, this study provides a foundation for more definitive investigations into IT adoption in construction organizations.

Limitation in this study may stem from the methodology. The study is purely theoretical and therefore needs empirical confirmation. Further study should therefore source for data and subject it to statistical analysis for a more concrete outcome.

\section{REFERENCES}

[1] Kezner, H. (1992). A Systems Approach to Planning Scheduling and Controlling. International Journal of Project Management, 12 , 316-321.

[2] Musa, N.A., Oyebisi, T.O., Babalola, M.O., (2010). A Study Of The Impact Of Information And Communications Technology (Ict) On The Quality Of Quantity Surveying Services In Nigeria, The Electronic Journal on Information Systems in Developing Countries, 42(7), 1-9.

[3] Usman, N., \& Said, I. (2014). Key Factors that Affects Adoption of Technology in the Nigerian Construction Firms: A Theoretical Framework. International Journal of Accounting, Business and Management, Vol. 2(2), 26-38

[4] Hameed, M. A., Counsell, S., \& Swift, S. (2012). A Conceptual Model for the Process of IT Innovation Adoption in Organizations. Journal of Engineering and Technology Management, 29(3), 358-390

[5] Susanty, A., Jie, F., \& Helvipriyanto, F. (2012, October). Model of Information Technology Adoption in Smes Batik Case Study Smes Batik Solo and Pekalongan. In 2012 International Conference on Information Management, Innovation Management and Industrial Engineering (Vol. 1, pp. 113-118). IEEE.

[6] Kurnia, S., Karnali, R. J., \& Rahim, M. M. (2015). A Qualitative Study of Business-to Business Electronic Commerce Adoption within the Indonesian Grocery Industry: A Multi-theory Perspective. Information and Management, 52(4), 518-536

[7] Alsaad, A. K., Mohamad, R., \& Ismail, N. A. (2014). The Moderating Role of Power Exercise in B2B E-commerce Adoption Decision. Procedia-Social and Behavioral Sciences, 130, 515-523

[8] Jokonya, O., Kroeze, J. H., \& van der Poll, J. A. (2012, October). Towards a Framework for Decision Making Regarding IT Adoption. Proceedings of the South African Institute for Computer Scientists and Information echnologists Conference (pp. 316-325). ACM

[9] Achuenu, E. (1999). Computer Applications in the Building Industry, Journal of Environmental Sciences 3(2), 239-244 
[10] Oladapo, A. A. (2006). The Impact of ICT on Professional Practice in The Nigerian Construction Industry. The Electronic Journal of Information Systems in Developing Countries, 24(2) 1-19

[11] Ibironke, O I, Ekundayo, D and Awodele, O A (2011). A Survey on the Use and Impact of Information Technology in Quantity Surveying Service Delivery in Nigeria. Procs 27th Annual ARCOM Conference, 5-7 September 2011, Bristol, UK, Association of Researchers in Construction Management, 433-442

[12] Apulu, I., \& Latham, A. (2009). Information and Communication Technology Adoption: Challenges for Nigerian Smes. TMC Academic Journal, 4(2), 64-80.

[13] Apulu, I., \& O. Ige, E. (2011). Are Nigeria SMEs Effectively Utilizing ICT? International Journal of Business and Management, 6(6), $207-214$

[14] Omeire, E., \& Omeire, C. (2014). New Wine in Old Wine Skin: An Exploration of Major Constraints to E-Government Implementation in Nigeria.European Scientific Journal, 10(14).

[15] Tornatzky, L.G. \& Fleischer, M. (1990): “The Process of Technology Innovation,” Lexington Books, Lexington, MA.

[16] Teo, T.S.H., Ranganathan, C., Dhaliwal, J., 2006. Key Dimensions of Inhibitors for The Deployment of Web-Based Business-ToBusiness Electronic Commerce. IEEE Transactions on Engineering Management 53 (3), 395-411.

[17] Jansen, K.J. (2004). From Persistence to Pursuit: A Longitudinal Examination of Momentum During the Early Stages of Strategic Change, Organization Science, 15(3), 276-294.

[18] Lin, H.F., Lee, G.G., 2005. Impact of Organizational Learning and Knowledge Management Factors on E-Business Adoption. Management Decision 43 (2), 171-188.

[19] Awa, H. O., Nwibere, B. M., \& Inyang, B. J. (2010). The Uptake Of Electronic Commerce By Smes : A Meta Theoretical Framework Expanding The Determining Constructs Of Tam And Toe Frameworks, Journal of Global Buisness and Technology, 6(1), 1-28.

[20] Gu, V. C., Cao, Q., \& Duan, W. (2012). Unified Modeling Language (UML) IT adoption-A holistic model of organizational capabilities perspective.Decision Support Systems, 54(1), 257-269.

[21] Medina-Garrido, J. A., Ruiz-Navarro, J., \& Bruque-Camara, S. (2005). Developing Dynamic Capabilities With IT. Strategic Capabilities And Knowledge Transfer Within And Between Organizations: New Perspectives From Acquisitions, Networks, Learning and Evolution, 156-175.

[22] Boonstra, A. (2013). How Do Top Managers Support Strategic Information System Projects and Why Do They Sometimes Withhold This Support? International Journal of Project Management 31(4), 498-512.

[23] Soliman K. S. and Janz B. D., (2004). "An Exploratory Study to Identify the Critical Factors Affecting the Decision to Establish Internet-Based Inter-Organizational Information Systems," Information Management, vol. 41 (6), pp. 697-707

[24] Ibironke, O. T., Ekundayo, D., \& Awodele, O. A. (2011). A Survey on the Use and Impact of Information Technology in Quantity Surveying Service Delivery in Nigeria, Proceedings 27th Annual ARCOM Conference (September), 433-442

[25] Liljander, V., Gillberg, F., Gummerus, J., \& van Riel, A. (2006). Technology Readiness and the Evaluation and Adoption of SelfService Technologies. Journal of Retailing and Consumer Services, 13(3), 177-191.

[26] van Dam, K., Oreg, S., \& Schyns, B. (2008). Daily Work Contexts and Resistance to Organizational Change: The Role Of LeaderMember Exchange, Perceived Development Climate and Change Process Characteristics. Applied Psychology: An International Review, 57, 313-334.

[27] Isa, R. B., Jimoh, R. A., \& Achuenu, E., (2013). An Overview of the Contribution of Construction Sector to Sustainable Development in Nigeria. Net Journal of Business Management, 1(1), 1-16

[28] Berger, A. N., \& Mester, L. J. (2003). Explaining the Dramatic Changes in Performance of US Banks: Technological Change, Deregulation, and Dynamic Changes in Competition. Journal of Financial Intermediation, 12(1), 57-95.

[29] Kaufman, B. E. (2015). Market Competition, HRM, and Firm Performance: The Conventional Paradigm Critiqued and Reformulated. Human Resource Management Review, 25(1), 107-125.

[30] Ollo-López, A., \& Aramendía-Muneta, M. E. (2012). ICT Impact on Competitiveness, Innovation and Environment. Telematics and Informatics, 29(2), 204-210.

[31] Kraemer, K.; Gurbaxani, V.; and King, J. (1992) Economic Development, Government Policy, and the Diffusion of Computing in Pacific Area Countries. Public Administration Review, 52, 2 146-156.

[32] Mohammadi, H. (2015). Factors Affecting the E-Learning Outcomes: An Integration of TAM and IS Success Model. Telematics and Informatics, 32(4), 701-719. 